\title{
Glial cells and energy balance
}

\author{
Pilar Argente-Arizón', Santiago Guerra-Cantera1, Luis Miguel Garcia-Segura², \\ Jesús Argente ${ }^{1}$ and Julie A Chowen ${ }^{1}$ \\ 1Departments of Pediatrics \& Pediatric Endocrinology, Hospital Infantil Universitario Niño Jesús, \\ Instituto de Investigación La Princesa, Department of Pediatrics, Universidad Autónoma de Madrid, \\ CIBEROBN, Instituto de Salud Carlos III, Madrid, Spain \\ IInstituto Cajal, Consejo Superior de Investigaciones Científicas (CSIC), Madrid, Spain
}

Correspondence should be addressed to J A Chowen Email julieann.chowen@salud. madrid.org

\begin{abstract}
The search for new strategies and drugs to abate the current obesity epidemic has led to the intensification of research aimed at understanding the neuroendocrine control of appetite and energy expenditure. This intensified investigation of metabolic control has also included the study of how glial cells participate in this process. Glia, the most abundant cell type in the central nervous system, perform a wide spectrum of functions and are vital for the correct functioning of neurons and neuronal circuits. Current evidence indicates that hypothalamic glia, in particular astrocytes, tanycytes and microglia, are involved in both physiological and pathophysiological mechanisms of appetite and metabolic control, at least in part by regulating the signals reaching metabolic neuronal circuits. Glia transport nutrients, hormones and neurotransmitters; they secrete growth factors, hormones, cytokines and gliotransmitters and are a source of neuroprogenitor cells. These functions are regulated, as glia also respond to numerous hormones and nutrients, with the lack of specific hormonal signaling in hypothalamic astrocytes disrupting metabolic homeostasis. Here, we review some of the more recent advances in the role of glial cells in metabolic control, with a special emphasis on the differences between glial cell responses in males and females.
\end{abstract}

\author{
Key Words \\ - hypothalamic \\ inflammation \\ - gliosis \\ - high-fat diet \\ - sexual dimorphism
}

\section{Introduction}

Glial cells play an active role in numerous physiological processes including neurogenesis, synaptogenesis and synaptic plasticity; they transport nutrients and metabolic factors essential for neuronal survival and function from the periphery into the brain and participate in synaptic transmission (Tsacopoulos \& Magistretti 1996, Kacem et al. 1998, Vesce et al. 1999). Glial cells are also the first line of defense in the central nervous system (CNS) highlighting the role of microglial cells in processes such as neuroinflammation and brain injury (Loane \& Kumar 2016) and contribute to the maintenance of the bloodbrain barrier (BBB) (Nakagawa et al. 2009, Abbott et al. 2010). Although glial cells throughout the CNS share many common functions, some of their responses/outputs vary, both between and within anatomical regions of the brain (Oberheim et al. 2012). These functional differences are most likely due to innate differences in glial populations, although we currently do not have sufficient information regarding this aspect, and due to their neuronal environment. That is, the physiological functions affected by glial cell activity are invariably linked to the output of the neurons in their local network.

Studies indicating that the activation of hypothalamic glial cells in response to high-fat diet (HFD) intake is involved in central inflammation and insulin resistance have drawn increasing attention to the role that these cells play in metabolic control (Thaler et al. 2012, Buckman et al. 2013, Valdearcos et al. 2014).

Published by Bioscientifica Ltd 
This HFD-induced inflammatory reaction specifically involves the hypothalamus (De Souza et al. 2005, Thaler et al. 2012, Wang et al. 2012, Berkseth et al. 2014), the key site for the regulation of energy balance. Indeed, numerous studies in animals have shown evidence of inflammation/gliosis in response to HFD (Thaler et al. 2012, Buckman et al. 2014, Valdearcos etal. 2014), whereas this has also been reported to occur in humans with an elevated body mass index (BMI) (Thaler et al. 2012). However, hypothalamic glial cells not only participate in pathological events, such as the inflammatory response that occurs as a consequence of HFD consumption (Milanski et al. 2009, Thaler et al. 2012, Buckman et al. 2014, Valdearcos et al. 2014, Yan et al. 2014), but they are also intricately involve in the physiological control of the surrounding neurons, including those dictating energy balance. The importance of this relationship is even further emphasized by the fact that these glial cells express receptors and systems of transport for numerous metabolic hormones and factors (Boyles et al. 1985, Vielkind et al. 1990, Zhu et al. 1990, Vannucci et al. 1997, Marty et al. 2005, Pan et al. 2008, Hsuchou et al. 2009, Baquedano et al. 2013), suggesting that at least part of the central effects of these metabolic signals are mediated through these non-neuronal cells. Thus, a deeper understanding of glial cell function will allow both a better understanding of their role in normal brain physiology, as well as their participation in pathological processes, and hopefully lead to the identification of new therapeutic targets for obesity treatment.

It is important to remember that the responses of males and females to obesity and its secondary complications are different (Palmer \& Clegg 2015). This is at least partially due to the influence of sex steroids, as the decline in estrogen levels that occurs in postmenopausal women is associated with an increased propensity to accumulate fat mass and the development of obesityassociated diseases compared to premenopausal women (Gambacciani et al. 1997). Unfortunately, most studies analyzing the glial response to obesity and HFD have been performed exclusively in males; thus, little is known as to whether sex differences in the hypothalamic glial response to metabolic cues are involved in the different propensities of males and females to develop obesity and its comorbidities. This possibility is suggested by the fact that glial cells present sexually dimorphic characteristics and responses, with these differences being at least partially due to the influence of sex steroids (Chowen et al. 1995, Melcangi et al. 2001, Acaz-Fonseca et al. 2016). Indeed, astrocytes express receptors for estrogens, androgens and progesterone (Pfaff \& Keiner 1973, Garcia-Segura et al. 1996b, Melcangi et al. 2001, Garcia-Ovejero et al. 2005) and sex steroids are reported to modulate the glial response to HFD (Louwe et al. 2012, Morselli et al. 2014). Sex steroids exert neuroprotective effects in various brain regions, with glial cells participating in this phenomenon (Azcoitia et al. 2003, Garcia-Ovejero et al. 2005, Barreto et al. 2009, Ghorbanpoor et al. 2014); thus, it is possible that sex hormones could protect against the deleterious effects of HFD-induced obesity on hypothalamic metabolic neuronal circuits by actions on the neighboring glia.

Here, we will review some of the current areas of interest regarding glial cell involvement in metabolic control. In addition, special emphasis will be placed on what is known regarding the differential responses of glial cells from males and females to metabolic signals.

\section{Glial cells in metabolic control}

Glia are the most abundant cell type in the CNS and are classified as microglia or macroglia, with the latter including astrocytes, tanycytes, oligodendrocytes and ependymal cells. Among these, microglia, astrocytes and tanycytes have been most clearly implicated in metabolic control, with some of their functions being summarized in Fig. 1.

\section{Astrocytes in metabolic control}

Astrocytes, the most bountiful cells within the brain, are clearly implicated in the physiological and pathophysiological control of metabolism, although the mechanisms by which they do so remain to be fully elucidated. Neuronal protection, maintenance and metabolism, anatomical support, synaptogenesis, synaptic connectivity and transmission, electrolyte and glucose homeostasis and cytokine production are all known functions performed by these 'star-shaped' cells (Nedergaard et al. 2003, Clarke \& Barres 2013). Together with blood vessels and neurons, astrocytes form a sensing unit that mediates the metabolic communication between the periphery and the CNS. Astrocytes participate, therefore, in the regulation of nutrient entry into the brain, serving as metabolic sensors and promoting neuronal survival and the maintenance of CNS homeostasis (Tsacopoulos \& Magistretti 1996, Abbott et al. 2010, Wang et al. 2014).

In addition to aiding in glucose and lipid sensing (Leloup et al. 2016), astrocytes express receptors for and respond to hormones implicated in the control of food

Published by Bioscientifica Ltd 


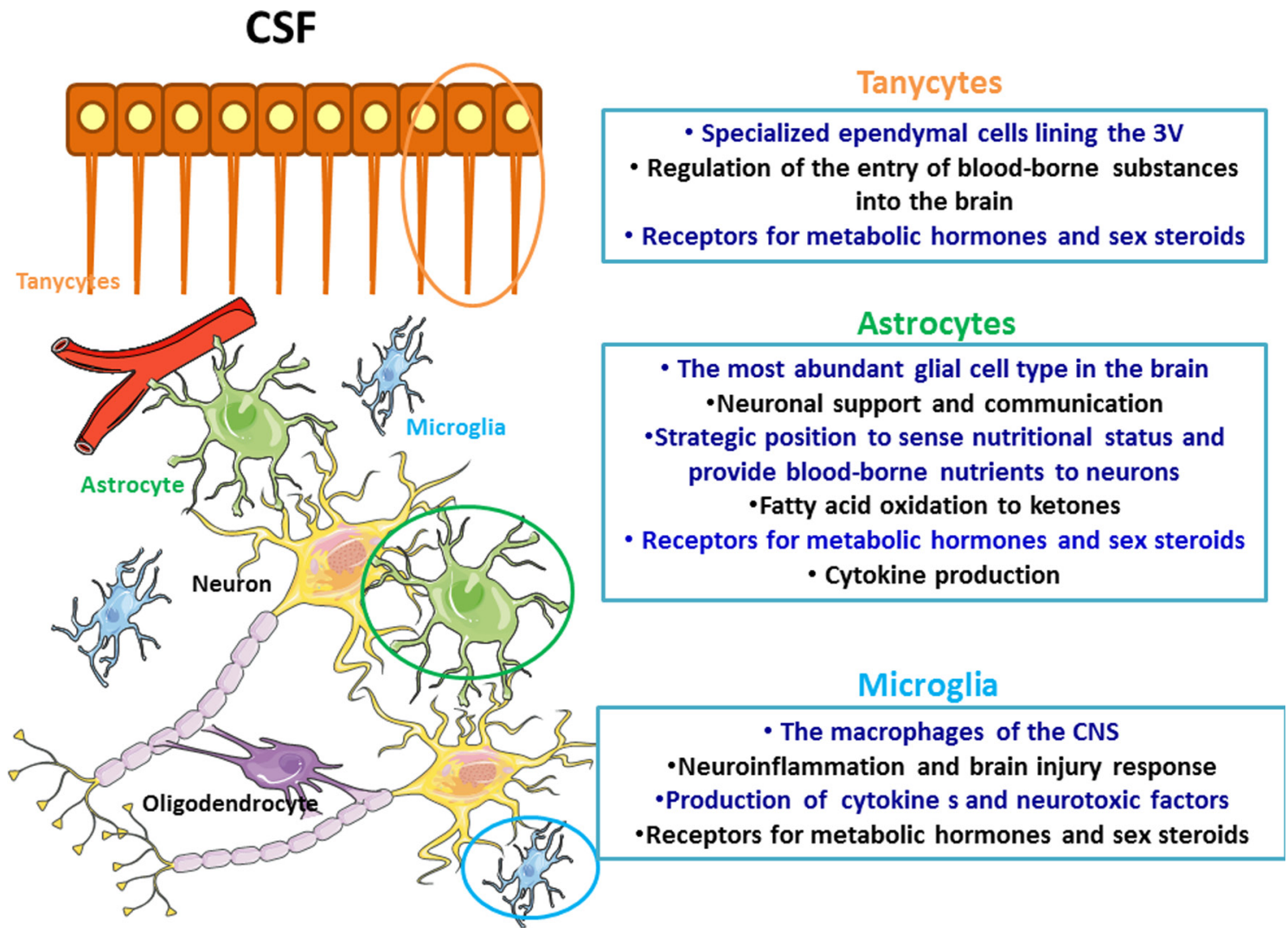

Figure 1

Summary of some of the most relevant functions performed by glial cells in metabolic control. Graphic illustration of the various cell types found in the central nervous system (CNS). Glial cells are the most abundant cell type in the CNS and are involved in both physiology and pathophysiology of energy homeostasis. Amongst glial cells, microglia, astrocytes and tanycytes have been most clearly implicated in metabolic control. 3V, third ventricle; CNS, central nervous system; CSF, cerebrospinal fluid.

intake, such as leptin, ghrelin and insulin (Diano et al. 1998a, Hsuchou et al. 2009, Baquedano et al. 2013, Kim et al. 2014). They are the only cells within the CNS able to beta-oxidize fatty acids (FAs) for the production of ketone bodies, which signals to the surrounding neurons. Many of these hormonal and metabolic factors have been shown to modify astrocytic morphology and functions, including their production of cytokines and/or other factors and their transport of nutrients and neurotransmitters (Garcia-Caceres et al. 2011, 2016, Gupta et al. 2012, Fuente-Martin et al. 2013). For example leptin, an important anorexic signal, modifies astrocyte morphology within the hypothalamus by changing the length and number of their primary projections (Garcia-Caceres et al. 2011, Kim et al. 2014). This is associated with changes in the extension of glial coverage and the number and balance of synaptic inputs on the local metabolic neurons, which in turn affects their functioning and output (Horvath et al. 2010, Kim et al. 2014). These modifications in astrocyte morphology could participate in the adaptation of hypothalamic neuronal circuits to new metabolic conditions, as seen in the acute stages of HFD consumption (Thaler et al. 2012, Buckman et al. 2014). However, if an adverse situation extends over time, such as extended HFD intake or longterm obesity, astrocytic modifications could possibly lead to, or be involved in, pathological situations. For example, astroctyes respond to both leptin and ghrelin, but the effects of these hormones on their synthesis and release of cytokines and on glutamate and glucose transport are both time dependent, with short- and longterm exposure often inducing completely opposite effects (Garcia-Caceres et al. 2011, Fuente-Martin et al. 2012a). It should also be kept in mind that cytokine release by astrocytes can have either beneficial or detrimental effects depending on the type, intensity and duration of the stimulus (Choi et al. 2014).

The physiological importance of metabolic hormone signaling in astrocytes has been clearly demonstrated by the study of genetically engineered animal models. Ablation of the leptin receptor (Ob-R) specifically in astrocytes modifies the synaptic organization of

Published by Bioscientifica Ltd 
the melanocortin system (Kim et al. 2014). Kim and coworkers demonstrated that the number and length of astrocytic primary projections are reduced in the absence of Ob-R, and this is associated with decreased astrocytic coverage of POMC neurons and modifications in the electrical activity of POMC and AgRP neurons (Kim et al. 2014). These anatomical and functional changes are associated with the attenuation of the anorexigenic response to leptin and augmentation of the ghrelininduced response to fasting. Moreover, when mice that specifically lack Ob-R in astrocytes are subjected to HFD, they appear to be resistant to the hyperleptinemia and leptin resistance provoked by diet-induced obesity (Jayaram et al. 2013).

More recently, the generation and study of animals lacking the insulin receptor in astrocytes, either throughout the brain or specifically in the mediobasal hypothalamus, indicate that insulin's action on hypothalamic astrocytes is directly involved in systemic glucose sensing (GarciaCaceres et al. 2016). The expression of insulin receptors in astrocytes was shown to be important for the uptake of insulin and glucose into the brain, and in the hypothalamus, the lack of insulin signaling in astrocytes impairs the normal response to changes in glycemia (Garcia-Caceres et al. 2016).

Astrocyte activation has also been shown to attenuate ghrelin-induced food intake and to facilitate the satiety effects of leptin (Yang et al. 2015). Yang and coworkers suggest that glial cells alter feeding by modulating extracellular levels of adenosine, which affects the firing rate of AgRP neurons (Yang et al. 2015). Ghrelin can also act directly on hypothalamic astrocytes, as not only do they express receptors for this orexigenic hormone (Baquedano et al. 2013, Fuente-Martin et al. 2016), but in vitro studies show that ghrelin modifies the ability of astrocytes to transport glutamate and glucose, as well as their expression of glutamine synthetase, lactate dehydrogenase, glycogen phosphorylase and lactate transporters (Fuente-Martin et al. 2016). These observations suggest a possible direct effect of ghrelin on glutamate and carbohydrate metabolism by astrocytes.

Evidence also indicates that nutrients, such as carbohydrates and FAs, can directly affect astrocytes. Fructose induces hypothalamic astrogliosis both in vivo and in vitro (Li et al. 2014). On the contrary, although high sucrose intake induces hypothalamic inflammation, this was not found to be associated with astrogliosis (FuenteMartin et al. 2013). Thus, the astroglial response may depend on what type of carbohydrate is ingested in excess, although further studies are necessary to determine the mechanisms underlying these differential responses and if they are involved in the final metabolic outcome.

Circulating FAs are elevated in obese individuals, and this is associated with adipocyte dysfunction and the development of insulin resistance (Boden \& Shulman 2002, Guilherme et al. 2008). This elevation also results in increased FA transport into the brain, with the type and degree of FA saturation being of great importance. Saturated FAs, such as palmitic acid, cause an inflammatory response in different cell types (Boden \& Shulman 2002, Iyer et al. 2010) in addition to endoplasmic reticulum (ER) stress (Gregor \& Hotamisligil 2007). The effects of long-chain saturated FAs are seen in both astrocytes and microglia, where they induce the release of inflammatory molecules. In contrast, this inflammation does not occur in response to non-saturated FAs (Milanski et al. 2009, Gupta et al. 2012, Morselli et al. 2014, Valdearcos et al. 2014). Thus, the astrocytic signals released to the surrounding neurons depend on the specific type of nutrient perceived by these cells and this in turn most likely affects neuronal metabolic sensing.

Some foods, such as those containing antioxidants, can exert protective effects in the CNS. Some of these effects appear to be mediated through astrocytes, although how these compounds exert their protection is only now beginning to be elucidated. One widely studied example is resveratrol, a polyphenol found in grapes, wine and blueberries. This antioxidant wields glioprotective actions by preventing mitochondrial damage in these cells, thus maintaining mitochondrial function and redox homeostasis (Bellaver et al. 2016). How these compounds could help to attenuate the effects of fat-rich diets through their protective actions on astrocytes deserves further investigation.

\section{Differences between males and females in the astrocytic response}

Role of estrogens As stated previously, astrocytes express receptors for estrogens, androgens and progesterone (Garcia-Segura et al. 1996a, Melcangi et al. 2001, Garcia-Ovejero et al. 2005, Acaz-Fonseca et al. 2016), with sex steroids possibly participating in the different astroglial responses observed in males and females as a consequence of weight gain and/or obesity. Estrogens are protective against weight gain, adiposity and obesityassociated complications (Stubbins et al. 2012, Dakin et al. 2015). These effects are mediated through estrogen receptor alpha $(\mathrm{ER} \alpha)$, as activation of this receptor regulates food intake, glucose homeostasis and energy

Published by Bioscientifica Ltd. 
expenditure (Musatov et al. 2007, Xu et al. 2011), with activation of ERs in the hypothalamic ventromedial nucleus specifically augmenting energy expenditure (Gambacciani et al. 1997, Musatov et al. 2007, Xu et al. 2011). Estrogens increase the activity of anorexigenic signals such as leptin and decrease orexigenic signals such as ghrelin (Tarttelin \& Gorski 1971, Clegg et al. 2006, 2007, Shen et al. 2010, Zhu et al. 2013). In this line, women undergo fluctuations in food intake depending on the phase of their menstrual cycle, for example, eating less during the periovulatory days, when estradiol concentrations are highest (Barr et al. 1995, Buffenstein et al. 1995, Davidsen et al. 2007). This phenomenon has also been demonstrated in female rodents (Tarttelin \& Gorski 1971, Asarian \& Geary 2013), sustaining the association between estradiol concentrations and food intake. Moreover, in response to HFD consumption, female rats gain less weight than males, but this differential response is no longer observed after ovariectomy (Stubbins et al. 2012), which is similar to the tendency for postmenopausal women to increase their body weight as their estrogen levels decrease (Brown et al. 2010, Hamilton et al. 2016). In fact, females are reported to be more resistant to obesity than males in part due to the higher expression of ER $\alpha$ in astrocytes (Morselli et al. 2015).

Astrocyte morphology changes throughout the estrous cycle in association with the fluctuations in sex steroid levels, with the opposition of astroglial cells to GnRH neurons decreasing when estradiol concentrations are high (Garcia-Segura \& McCarthy 2004). In contrast, astrocyte surface contact with non-GnRH neurons in the hypothalamic arcuate nucleus is increased when estradiol concentrations are elevated (Garcia-Segura \& McCarthy 2004, Gao et al. 2007). As mentioned previously, these differential responses may be due to innate differences in astrocytes and/or to their local environment and possible interaction with surrounding cells. The effects of estrogens and sex hormones on astrocytes and how astrocytes differ between males and females, as well as the molecular mechanisms involved, are not well understood and an important area to be explored.

\section{Astrocytes in pathophysiological response to high-fat diets and obesity}

Consumption of HFD can lead to overweight and obesity, and in consequence, disruption of metabolic status and comorbidities. Obesity is characterized by a low-grade inflammatory state, not only involving the periphery but, as mentioned previously, also the hypothalamus, with this possibly involving hypothalamic astrogliosis (De Souza et al. 2005, Milanski et al. 2009, Thaler et al. 2012). Astrogliosis can be defined as a change in astrocyte number and/or morphology, which can lead to modifications in their contacts with neurons, including their ensheathment of neuronal somas, and the number of synaptic inputs to these neurons. Indeed, an increase or a decrease in the number of primary astrocytic projections can lead to changes in cell-to-cell communication, contact with blood vessels and changes in synaptic inputs in metabolic circuits (Horvath et al. 2010). For example, there is a reduction in the number of synapses on POMC perikarya as a consequence of synaptic reorganization due to HFD intake (Horvath et al. 2010). Modifications in astrocyte number or morphology can also be accompanied by the release of inflammatory cytokines and neurotoxic factors associated with oxidative stress. In overweight or obesity, the excess adiposity is associated with an increase in the circulating concentrations of leptin, as well as in FAs, that can directly activate astrocytes (GarciaCaceres et al. 2011, Gupta et al. 2012), thus suggesting that hypothalamic inflammation and gliosis are a result of dietary factors and hormonal changes associated with increased adiposity.

Activation of astrocytes is reported to occur as early as $24 \mathrm{~h}$ after HFD consumption (Thaler et al. 2012, Buckman et al. 2014). This rapid activation could function initially as a neuroprotective response and an attempt to maintain energy homeostasis. The downside of this 'activation' occurs when it is sustained over time; inflammatory and neurotoxic factors released by astrocytes can cause neuronal damage (Pekny \& Pekna 2014), and it is possible that the plasticity of the system, including changes in glial-neuronal interactions and synaptic inputs, could also be affected. This astrogliosis can be prolonged as a consequence of long-term HFD consumption, where peripheral FA concentrations rise and thus the amount of FAs reaching the brain where they can directly activate glial cells (Gupta et al. 2012). As mentioned previously, saturated FAs induce the release of cytokines in the hypothalamus, whereas this is not observed in response to unsaturated FAs (Milanski et al. 2009). One possible outcome of prolonged hypothalamic inflammation/astrocytosis is the development of leptin and insulin resistance, further provoking the disruption of energy homeostasis and perpetuating the complications associated with overweight and obesity (Carvalheira et al. 2003, De Souza et al. 2005).

Published by Bioscientifica Ltd. 


\section{Sex differences in the astroglial response to FAs}

The activation of astrocytes by FAs is different between the sexes and can be modulated by sex steroids. Moreover, females may be more resistant than males to obesityassociated secondary effects due, at least in part, to the higher expression of ERo in astrocytes (Morselli et al. 2014). Thus, the sex differences observed in these cells could possibly participate in the sexually dimorphic inflammatory response to HFDs (Louwe et al. 2012, Morselli et al. 2014).

Most studies of experimental obesity have used HFDs to induce weight gain; however, increased adipose tissue accrual can also occur under other circumstances, and astrocytic changes are also observed in some of these animal models (Garcia-Caceres et al. 2011, Fuente-Martin et al. 2012a, Gao et al. 2014). This indicates that astroglial responses are not due to dietary signals, such as FAs, alone. Indeed, systemic changes that result from increased weight gain, such as increased circulating leptin levels, most likely participate in this process. The metabolic response to some of these other paradigms of overweight/obesity induction, such as high sucrose intake and the long-term effects of neonatal overnutrition also differs between male and female rodents (Fuente-Martin et al. 2012b), and the response of hypothalamic astrocytes appear to differ between the sexes in these experimental models also (P Argente-Arizón, J Argente \& JA Chowen, unpublished observations).

\section{Tanycytes in metabolic control}

Our understanding of how tanycytes participate in the control of feeding has increased dramatically in recent years. Tanycytes are specialized ependymal cells occupying the floor and the ventro-lateral walls of the third ventricle (3V) of the hypothalamus. There are two major subtypes of tanycytes that are classified as either $\alpha$ or $\beta$, with their differences residing in both their localization and biological functions (Rodriguez et al. 2005, Goodman $\&$ Hajihosseini 2015). Along with capillary endothelia, these glial cells regulate BBB permeability and therefore the entry of blood-borne substances into the brain. The privileged localization of tanycytes grants them a key role in determining whether molecules will be allowed into the CNS, resulting in these cells being referred to as 'gatekeepers'. This process also involves the regulation of nutrients and hormones into the hypothalamus, which in turn determines the signals reaching metabolic neuronal circuits and their subsequent responses; this ultimately affects appetite, metabolism and body weight.
Tanycytes connect the cerebrospinal fluid (CSF) with metabolic neuronal circuits in the arcuate and ventromedial nuclei of the hypothalamus through long processes, with this communication being modified by an individual's nutritional and hormonal status. The expression of glucose transporter 2 (GLUT2) in tanycytes is fundamental for their glucose-sensing properties (García et al. 2003, Salgado et al. 2014), a process that is essential for the appropriate response to hypoglycemia (Sanders et al. 2004). Indeed, these specialized glial cells reorganize themselves under fasting conditions to evoke adequate responses to control glucose homeostasis (Langlet et al. 2013). Their adaptive responses to their environment involve the regulation of BBB permeability by releasing vascular endothelial growth factor A (VEGF-A) (Langlet et al. 2013), which facilitates increased communication between circulating metabolites and metabolic neurons.

Tanycyte-regulated passage of specific metabolic signals, such as leptin, across the BBB and into the hypothalamus requires the activation of the ERK signaling pathway (Balland et al. 2014). This mechanism for leptin transport into the brain is compromised in situations of chronic HFD intake (Balland et al. 2014) and may contribute to the development of decreased central leptin signaling. Obesity during gestation has also been shown to alter BBB permeability by, among other things, reducing tanycyte processes at the level of the arcuate nucleus (Kim et al. 2016).

The participation of tanycytes in thyroid hormone (TH) metabolism was first suggested when they were shown to express deiodinase enzyme II (Dio2) (Diano et al. 1998b), the molecule responsible for the conversion of the prohormone $\mathrm{T}_{4}$ into the active form, $\mathrm{T}_{3}$. These glial cells capture $\mathrm{T}_{4}$ from the peripheral circulation and then liberate $\mathrm{T}_{3}$ into the hypothalamus (Barrett et al. 2007) where it regulates, for example, the response of the orexigenic NPY/AgRP neurons (Coppola et al. 2007). The expression of Dio2 is increased in these glial cells in conditions of starvation or inflammation and follows a photoperiodic pattern in seasonal mammals (Bolborea et al. 2015). In rats, the intracerebroventricular administration of TSH for 2 weeks increases Dio2 levels in the ependymal layer (Helfer et al. 2013) and TSH also stimulates Dio2 synthesis in vitro in primary tanycyte cultures (Bolborea et al. 2015), indicating a direct effect on these cells. Indeed, they express the TSH receptor (TSHR), with TSHR expression being very high in the ventral region of the ependyma lining the third ventricle (Bolborea et al. 2015), an area with a high density of tanycytes. The response of

Published by Bioscientifica Ltd 
tanycytes to TSH elicits both an increase in cAMP levels and ERK1/2 activation (Bolborea et al. 2015), but it is still unclear if this signaling is common to all tanycytes or if it is region specific (Bolborea et al. 2015). In summary, tanycytes determine the $T_{3}$ levels in the hypothalamus through Dio2 activity, which is modulated by TSH levels in the third ventricle.

Tanycytes can serve as progenitor cells in both the postnatal and adult brains, differentiating into both neurons and astrocytes (Oyarce \& Nualart 2014), with tanycytes in the median eminence exhibiting high neurogenic potential (Lee et al. 2014). In adulthood, neurogenesis in the hypothalamus is regulated by specific hormones, including estradiol levels, growth factors such as IGF1, and the nutritional status and the type of diet ingested (Perez-Martin et al. 2003, Migaud et al. 2010, Lee et al. 2012, 2014, Bless et al. 2014). IGF-1, a growth factor known to be involved in metabolism (Brown-Borg \& Bartke 2012, Sadagurski \& White 2013), is also reported to stimulate the proliferation of tanycytes (Mirzadeh et al. 2008, Rojczyk-Golebiewska et al. 2014). In the brain, the common signaling pathway between IGF-1 and insulin acting through IRS2 constitutes a link between complex events such as metabolic modulation, life span and, at least in mammals, cognition (White 2014).

In the hypothalamus, HFD intake has an anatomically specific effect on neurogenesis, inhibiting it in the mediobasal hypothalamic parenchyma and enhancing it in the median eminence in female mice, with this response being sexually dimorphic (Lee et al. 2014). The enhancement of neurogenesis in the median eminence appears to be associated to its anatomical location as it is in contact with the third ventricle, and exposed to hormones, molecules and factors from the cerebrospinal fluid and blood and is purported to restore the neurons that die as a result of the toxic effect of HFD (Lee et al. 2014). However, the mechanism that underlies the sexually dimorphic responses to HFD in the hypothalamus remains to be elucidated.

Dietary intake not only affects neurogenesis in the hypothalamus but also other brain structures, such as the hippocampus, which is known to maintain neurogenesis even in adulthood (Park et al. 2010). In the hippocampus, HFD reduces neurogenesis in the dentate gyrus (Lindqvist et al. 2006) and triggers oxidative stress and lipid peroxidation (Park et al. 2010), with the lipotoxicity caused by palmitic acid affecting the neural progenitor cells (NPCs) (Park et al. 2011), which is associated with a reduction in hippocampal brain-derived neurotrophic factor (BDNF) levels (Park et al. 2010). Lindqvist and coworkers reported that an increase in corticosterone levels is also involved in HFD-induced decrease in hippocampal neurogenesis, with males being more affected than females (Lindqvist et al. 2006). In contrast, dietary restriction results in higher levels of BDNF and neurotrophin-3 (NT-3), with an increase in neurogenesis (Lee et al. 2002). In accordance with this, moderate aerobic exercise is reported to stimulate adult hippocampal neurogenesis in rodents (Nokia et al. 2016), taking part in hippocampal-dependent memory, such as that needed in place conditioning (Shors et al. 2001) and reinforcing synaptic connections in pre-existing neurons by changes in neural plasticity (Trejo et al. 2008, LlorensMartin et al. 2010). These dietary effects on hippocampal neurogenesis could possibly be involved in feeding behavior and other conductual phenomena (Stangl \& Thuret 2009).

Tanycytes are also influenced by sex steroids and participate in the neuroendocrine regulation of puberty by liberating growth factors such as transforming growth factor beta (TGF $\beta$ ) that stimulates the synthesis and release of GnRH (Ojeda et al. 2010) and thus participating in the onset of puberty. Moreover, akin to astrocytes, estrogens modulate tanycyte plasticity similarly to what happens in fasting conditions. For example, tanycyte processes retract in response to the preovulatory surge of gonadotropins, facilitating an increase in the contact of GnRH neurons with blood vessels and the following secretion to the circulation (Prevot 2002). This retraction of tanycytic processes, and thus GnRH release, seems to be essential for the correct regulation of the female reproductive cycle (Ojeda et al. 1975). However, how estrogen regulation of tanycytes might affect metabolism requires further investigation.

The participation of tanycytes in metabolic and neuroendocrine control seems to be of undeniable importance; nonetheless, the effect of different metabolites and nutrients, such as the various types of FAs, on these glial cells and the specific outcomes are areas of research yet to be fully explored. Likewise, whether the tanycytic response to metabolic signals differs between males and females is yet to be determined.

\section{Microglia in metabolic control}

Microglial cells are considered to be the macrophages of the CNS (Rivest 2009), as they areconstantly removing damaged cells and debris and are the first barrier against infections and pathogens, with their main role being to maintain a healthy brain (Aloisi 2001, Nimmerjahn et al. 2005). These glial cells can adopt different states depending on the surrounding environment. On the one hand,

Published by Bioscientifica Ltd 
under physiological conditions, they appear as 'resting or ramified microglia' performing a variety of functions including modulation of synapses (Batchelor et al. 1999, Zhong et al. 2010) and production of certain substances such as cytokines when necessary. On the other hand, when environmental conditions are adverse, for example, when there is an overload of nutrients due to overnutrition or HFD consumption, they become reactive, undergoing morphological changes and releasing diverse factors. HFD intake (Thaler et al. 2012) and specifically saturated FAs (Milanski et al. 2009) activate microglia within the hypothalamus with this activation entailing the release of inflammatory cytokines and other factors such as nitric oxide (NO) or reactive oxygen species (ROS) by these cells. If the release of these inflammatory and oxidative stress factors becomes chronic, microglia reactivity worsens, causing toxicity in the surrounding area and possibly affecting neighboring neurons. Hypothalamic POMC neurons have been shown to be particularly vulnerable to this reaction (Block \& Hong 2007). Microglia are responsive to metabolic neuropeptides, with NPY and $\alpha \mathrm{MSH}$ modulating their secretion of cytokines and NO (Delgado et al. 1998, Ferreira et al. 2011). Therefore, there appears to be cross-talk between metabolic neurons and microglial cells, which possibly participates in the inflammatory process in obesity.

In addition to the direct effect of FAs on microglia (Milanski et al. 2009, Valdearcos et al. 2014), these glial cells can also be activated by hormonal signals such as the anorexigenic peptide leptin (Tang et al. 2007, Lafrance et al. 2010, Gao et al. 2014), with this hormone most likely participating in microglial activation in obese individuals. Indeed, Gao and coworkers (Gao et al. 2014) reported that transgenic ob/ob mice, which are obese due to the lack of leptin, actually present lower levels of microglial activation in the hypothalamus than control mice. Although HFD intake increased the activation of microglia in the hypothalami of ob/ob mice, it did not reach that seen in control levels. Thus, both nutrient and hormonal signals are involved in microglial activation in response to HFD. Moreover, leptin administration was sufficient to trigger microglial activation, independently of body weight (Gao et al. 2014).

Liberation of proinflammatory cytokines and potential neurotoxic factors by microglial cells may also take part in the development of insulin and/or leptin resistance that can occur in conjunction with central inflammation (De Souza et al. 2005, Shoelson et al. 2006). In contrast, physical activity counteracts the microglial activation induced by HFD, in addition to improving glucose tolerance (Yi et al. 2012).

The development and maturation of these immune cells are modulated by the early nutritional environment, with poor nutrition possibly affecting the response of these cells to future challenges (Bilbo et al. 2010, Clarke et al. 2012). For example, in nonhuman primate mothers fed a HFD during gestation, development of the melanocortin circuit in the offspring was affected by proinflammatory cytokines released by microglia (Grayson et al. 2010). Likewise, rodents born to mothers ingesting a HFD during gestation have increased microglial activation in the hippocampus at birth, as well as increased hippocampal microglial density in adulthood (Bilbo \& Tsang 2010). Overnutrition during lactation results in microglial activation in the hypothalamus and other brain areas when these animals reach adulthood, in addition to having increased expression of inflammatory cytokines in the hypothalamus (Tapia-González et al. 2011, Tu et al . 2011, Ziko et al. 2014).

The responses of microglia may differ between the sexes, as these cells express receptors for estrogens and progesterone. The number and morphology of microglia in some brain areas are reported to be different between the sexes (Schwarz et al. 2012). Although there is little information regarding whether these cells respond differently to metabolic challenges in males and females, estradiol is known to reduce microglia reactivity (Baker et al. 2004, Tapia-Gonzalez et al. 2008) and decrease the secretion of inflammatory cytokines in astrocytes (Cerciat et al. 2010, Rubio et al. 2011). Moreover, estrogens and progesterone can block inflammatory cytokine secretion by microglial cells, promoting an antiinflammatory state (Habib et al. 2013, Lei et al. 2014). However, further research is needed to investigate the effects of sex steroids in the response of microglia to metabolic signals.

\section{Concluding remarks}

Evidence has accumulated in the past decade to support a role for glial cells in the neuroendocrine control of metabolism. However, the mechanisms involved in the regulation of energy balance by these cells are far from being understood. Not only do the changes in peripheral hormones produced as a consequence of overweight and/ or obesity affect these cells but also the diet. Moreover, it is not just the amount of energy ingested, but the type of nutrients ingested. Indeed, different effects are observed

Published by Bioscientifica Ltd. 
depending on the type and the degree of saturation of FAs and an equilibrium between antioxidants and the production of ROS is important to maintain the correct functioning of these cells. Thus, future studies of how glial cells respond to specific nutrients and hormonal changes are of great importance, as their responses will ultimately determine the signals reaching neuronal circuits.

Studies have also started to highlight the fact that males and females respond differently to metabolic challenges, and that it is possible that glial cells are involved in this phenomenon, although more studies are required to directly compare the responses of these cells to hormonal and nutritional challenges in males and females. This will allow the scientific community to not only further understand how glial cells participate in the physiological and pathophysiological control of metabolism but also the mechanisms involved in the differential metabolic responses of males and females, and thus hopefully the design of more refined treatments for metabolic disorders according to each sex.

\section{Declaration of interest}

The authors declare that there is no conflict of interest that could be perceived as prejudicing the impartiality of this review.

\section{Funding}

The authors are funded by grants from Ministerio de Ciencia e Innovación (BFU2014-51836-C2-1-R and BFU2014-51836-C2-2-R), Fondo de Investigación Sanitaria (PI1302195), and Fondos FEDER, Centro de Investigación Biomédica en Red Fisiopatología de Obesidad y Nutrición (CIBEROBN) Instituto de Salud Carlos III and Fundación de Endocrinología y Nutrición.

\section{References}

Abbott NJ, Patabendige AA, Dolman DE, Yusof SR \& Begley DJ 2010 Structure and function of the blood-brain barrier. Neurobiology of Disease 37 13-25. (doi:10.1016/j.nbd.2009.07.030)

Acaz-Fonseca E, Avila-Rodriguez M, Garcia-Segura LM \& Barreto GE 2016 Regulation of astroglia by gonadal steroid hormones under physiological and pathological conditions. Progress in Neurobiology 144 5-26. (doi:10.1016/j.pneurobio.2016.06.002)

Aloisi F 2001 Immune function of microglia. Glia 36 165-179. (doi:10.1002/glia.1106)

Asarian L \& Geary N 2013 Sex differences in the physiology of eating. American Journal of Physiology: Regulatory, Integrative and Comparative Physiology 305 R1215-R1267.

Azcoitia I, Sierra A, Veiga S \& Garcia-Segura LM 2003 Aromatase expression by reactive astroglia is neuroprotective. Annals of the New York Academy of Sciences 1007 298-305. (doi:10.1196/annals.1286.028)

Baker AE, Brautigam VM \& Watters JJ 2004 Estrogen modulates microglial inflammatory mediator production via interactions with estrogen receptor beta. Endocrinology 145 5021-5032. (doi:10.1210/ en.2004-0619)
Balland E, Dam J, Langlet F, Caron E, Steculorum S, Messina A, Rasika S, Falluel-Morel A, Anouar Y, Dehouck B, et al. 2014 Hypothalamic tanycytes are an ERK-gated conduit for leptin into the brain. Cell Metabolism 19 293-301. (doi:10.1016/j.cmet.2013.12.015)

Baquedano E, Chowen JA, Argente J \& Frago LM 2013 Differential effects of GH and GH-releasing peptide- 6 on astrocytes. Journal of Endocrinology 218 263-274. (doi:10.1530/JOE-13-0053)

Barr SI, Janelle KC \& Prior JC 1995 Energy intakes are higher during the luteal phase of ovulatory menstrual cycles. American Journal of Clinical Nutrition 61 39-43.

Barreto G, Santos-Galindo M, Diz-Chaves Y, Pernía O, Carrero P, Azcoitia I \& Garcia-Segura LM 2009 Selective estrogen receptor modulators decrease reactive astrogliosis in the injured brain: effects of aging and prolonged depletion of ovarian hormones. Endocrinology 150 5010-5015. (doi:10.1210/en.2009-0352)

Barrett P, Ebling FJP, Schuhler S, Wilson D, Ross AW, Warner A, Jethwa P, Boelen A, Visser TJ, Ozanne DM, et al. 2007 Hypothalamic thyroid hormone catabolism acts as a gatekeeper for the seasonal control of body weight and reproduction. Endocrinology 148 3608-3617. (doi:10.1210/en.2007-0316)

Batchelor PE, Liberatore GT, Wong JY, Porritt MJ, Frerichs F, Donnan GA \& Howells DW 1999 Activated macrophages and microglia induce dopaminergic sprouting in the injured striatum and express brain-derived neurotrophic factor and glial cell line-derived neurotrophic factor. Journal of Neuroscience 19 1708-1716.

Bellaver B, Bobermin LD, Souza DG, Rodrigues MD, de Assis AM, Wajner M, Goncalves CA, Souza DO \& Quincozes-Santos A 2016 Signaling mechanisms underlying the glioprotective effects of resveratrol against mitochondrial dysfunction. Biochimica et Biophysica Acta 1862 1827-1838. (doi:10.1016/j. bbadis.2016.06.018)

Berkseth KE, Guyenet SJ, Melhorn SJ, Lee D, Thaler JP, Schur EA \& Schwartz MW 2014 Hypothalamic gliosis associated with high-fat diet feeding is reversible in mice: a combined immunohistochemical and magnetic resonance imaging study. Endocrinology $\mathbf{1 5 5}$ 2858-2867. (doi:10.1210/en.2014-1121)

Bilbo SD \& Tsang V 2010 Enduring consequences of maternal obesity for brain inflammation and behavior of offspring. FASEB Journal $\mathbf{2 4}$ 2104-2115. (doi:10.1096/fj.09-144014)

Bilbo SD, Wieseler JL, Barrientos RM, Tsang V, Watkins LR \& Maier SF 2010 Neonatal bacterial infection alters fever to live and simulated infections in adulthood. Psychoneuroendocrinology 35 369-381. (doi:10.1016/j.psyneuen.2009.07.014)

Bless EP, Reddy T, Acharya KD, Beltz BS \& Tetel MJ 2014 Oestradiol and diet modulate energy homeostasis and hypothalamic neurogenesis in the adult female mouse. Journal of Neuroendocrinology 26 805-816. (doi:10.1111/jne.12206)

Block ML \& Hong JS 2007 Chronic microglial activation and progressive dopaminergic neurotoxicity. Biochemical Society Transactions $\mathbf{3 5}$ 1127-1132. (doi:10.1042/BST0351127)

Boden G \& Shulman GI 2002 Free fatty acids in obesity and type 2 diabetes: defining their role in the development of insulin resistance and beta-cell dysfunction. European Journal of Clinical Investigation 32 (Supplement 3) 14-23. (doi:10.1046/j.1365-2362.32.s3.3.x)

Bolborea M, Helfer G, Ebling FJ \& Barrett P 2015 Dual signal transduction pathways activated by TSH receptors in rat primary tanycyte cultures. Journal of Molecular Endocrinology 54 241-250. (doi:10.1530/JME-14-0298)

Boyles JK, Pitas RE, Wilson E, Mahley RW \& Taylor JM 1985 Apolipoprotein E associated with astrocytic glia of the central nervous system and with nonmyelinating glia of the peripheral nervous system. Journal of Clinical Investigation 76 1501-1513. (doi:10.1172/JCI112130)

Brown-Borg HM \& Bartke A 2012 GH and IGF1: roles in energy metabolism of long-living GH mutant mice. Journals of Gerontology http://jme.endocrinology-journals.org

DOI: 10.1530/JME-16-0182
() 2017 Society for Endocrinology Printed in Great Britain
Published by Bioscientifica Ltd 
Series A: Biological Sciences and Medical Sciences 67 652-660. (doi:10.1093/gerona/gls086)

Brown LM, Gent L, Davis K \& Clegg DJ 2010 Metabolic impact of sex hormones on obesity. Brain Research 1350 77-85. (doi:10.1016/j. brainres.2010.04.056)

Buckman LB, Thompson MM, Moreno HN \& Ellacott KL 2013 Regional astrogliosis in the mouse hypothalamus in response to obesity. Journal of Comparative Neurology 521 1322-1333. (doi:10.1002/ cne.23233)

Buckman LB, Thompson MM, Lippert RN, Blackwell TS, Yull FE \& Ellacott KLJ 2014 Evidence for a novel functional role of astrocytes in the acute homeostatic response to HFD. Molecular Metabolism 4 58-63. (doi:10.1016/j.molmet.2014.10.001)

Buffenstein R, Poppitt SD, McDevitt RM \& Prentice AM 1995 Food intake and the menstrual cycle: a retrospective analysis, with implications for appetite research. Physiology and Behavior $\mathbf{5 8}$ 1067-1077. (doi:10.1016/0031-9384(95)02003-9)

Carvalheira JBC, Ribeiro EB, Araújo EP, Guimarães RB, Telles MM, Torsoni M, Gontijo JAR, Velloso LA \& Saad MJA 2003 Selective impairment of insulin signalling in the hypothalamus of obese Zucker rats. Diabetologia 46 1629-1640. (doi:10.1007/s00125-0031246-x)

Cerciat M, Unkila M, Garcia-Segura LM \& Arevalo MA 2010 Selective estrogen receptor modulators decrease the production of interleukin- 6 and interferon-gamma-inducible protein-10 by astrocytes exposed to inflammatory challenge in vitro. Glia $\mathbf{5 8}$ 93-102. (doi:10.1002/glia.20904)

Clarke LE \& Barres BA 2013 Emerging roles of astrocytes in neural circuit development. Nature Reviews Neuroscience 14 311-321. (doi:10.1038/nrn3484)

Clarke MA, Stefanidis A \& Spencer SJ 2012 Postnatal overfeeding leads to obesity and exacerbated febrile responses to lipopolysaccharide throughout life. Journal of Neuroendocrinology 24 511-524. (doi:10.1111/j.1365-2826.2011.02269.x)

Clegg DJ, Brown LM, Woods SC \& Benoit SC 2006 Gonadal hormones determine sensitivity to central leptin and insulin. Diabetes $\mathbf{5 5}$ 978-987. (doi:10.2337/diabetes.55.04.06.db05-1339)

Clegg DJ, Brown LM, Zigman JM, Kemp CJ, Strader AD, Benoit SC, Woods SC, Mangiaracina M \& Geary N 2007 Estradiol-dependent decrease in the orexigenic potency of ghrelin in female rats. Diabetes 56 1051-1058. (doi:10.2337/db06-0015)

Coppola A, Liu Z, Andrews Z, Paradis E, Roy M, Friedman JM, Ricquier D, Richard D, Horvath TL, Gao X, et al. 2007 A central thermogenic-like mechanism in feeding regulation: an interplay between arcuate nucleus T3 and UCP2. Cell Metabolism 5 21-33. (doi:10.1016/j.cmet.2006.12.002)

Choi SS, Lee HJ, Lim I, Satoh J \& Kim SU 2014 Human astrocytes: secretome profiles of cytokines and chemokines. PLOS ONE 9 e92325. (doi:10.1371/journal.pone.0092325)

Chowen JA, Busiguina S \& Garcia-Segura LM 1995 Sexual dimorphism and sex steroid modulation of glial fibrillary acidic protein messenger RNA and immunoreactivity levels in the rat hypothalamus. Neuroscience 69 519-532. (doi:10.1016/03064522(95)00250-M)

Dakin RS, Walker BR, Seckl JR, Hadoke PW \& Drake AJ 2015 Estrogens protect male mice from obesity complications and influence glucocorticoid metabolism. International Journal of Obesity 39 1539-1547. (doi:10.1038/ijo.2015.102)

Davidsen L, Vistisen B \& Astrup A 2007 Impact of the menstrual cycle on determinants of energy balance: a putative role in weight loss attempts. International Journal of Obesity 31 1777-1785. (doi:10.1038/ sj.ijo.0803699)

De Souza CT, Araujo EP, Bordin S, Ashimine R, Zollner RL, Boschero AC, Saad MJ \& Velloso LA 2005 Consumption of a fatrich diet activates a proinflammatory response and induces insulin resistance in the hypothalamus. Endocrinology $1464192-4199$. (doi:10.1210/en.2004-1520)

Delgado R, Carlin A, Airaghi L, Demitri MT, Meda L, Galimberti D, Baron P, Lipton JM \& Catania A 1998 Melanocortin peptides inhibit production of proinflammatory cytokines and nitric oxide by activated microglia. Journal of Leukocyte Biology 63 740-745.

Diano S, Kalra SP \& Horvath TL 1998 a Leptin receptor immunoreactivity is associated with the Golgi apparatus of hypothalamic neurons and glial cells. Journal of Neuroendocrinology 10 647-650. (doi:10.1046/j.1365-2826.1998.00261.x)

Diano S, Naftolin F, Goglia F, Csernus V \& Horvath TL $1998 b$ Monosynaptic pathway between the arcuate nucleus expressing glial type II iodothyronine 5 '-deiodinase mRNA and the median eminence-projective TRH cells of the rat paraventricular nucleus. Journal of Neuroendocrinology 10 731-742. (doi:10.1046/j.13652826.1998.00204.x)

Ferreira R, Santos T, Viegas M, Cortes L, Bernardino L, Vieira OV \& Malva JO 2011 Neuropeptide Y inhibits interleukin-1beta-induced phagocytosis by microglial cells. Journal of Neuroinflammation $\mathbf{8} 169$ (doi:10.1186/1742-2094-8-169)

Fuente-Martin E, Garcia-Caceres C, Granado M, de Ceballos ML, Sanchez-Garrido MA, Sarman B, Liu ZW, Dietrich MO, Tena-Sempere M, Argente-Arizon P, et al. 2012a Leptin regulates glutamate and glucose transporters in hypothalamic astrocytes. Journal of Clinical Investigation 122 3900-3913. (doi:10.1172/ JCI64102)

Fuente-Martin E, Granado M, Garcia-Caceres C, Sanchez-Garrido MA, Frago LM, Tena-Sempere M, Argente J \& Chowen JA 2012b Early nutritional changes induce sexually dimorphic long-term effects on body weight gain and the response to sucrose intake in adult rats. Metabolism 61 812-822. (doi:10.1016/j. metabol.2011.11.003)

Fuente-Martin E, Garcia-Caceres C, Diaz F, Argente-Arizon P, Granado M, Barrios V, Argente J \& Chowen JA 2013 Hypothalamic inflammation without astrogliosis in response to high sucrose intake is modulated by neonatal nutrition in male rats. Endocrinology 154 2318-2330. (doi:10.1210/en.2012-2196)

Fuente-Martin E, Garcia-Caceres C, Argente-Arizon P, Diaz F, Granado M, Freire-Regatillo A, Castro-Gonzalez D, Ceballos ML, Frago LM, Dickson SL, et al. 2016 Ghrelin regulates glucose and glutamate transporters in hypothalamic astrocytes. Scientific Reports 623673. (doi:10.1038/srep23673)

Gambacciani M, Ciaponi M, Cappagli B, Piaggesi L, De Simone L, Orlandi R \& Genazzani AR 1997 Body weight, body fat distribution, and hormonal replacement therapy in early postmenopausal women. Journal of Clinical Endocrinology and Metabolism 82 414-417. (doi:10.1210/jcem.82.2.3735)

Gao Q, Mezei G, Nie Y, Rao Y, Choi CS, Bechmann I, Leranth C, Toran-Allerand D, Priest CA, Roberts JL, et al. 2007 Anorectic estrogen mimics leptin"s effect on the rewiring of melanocortin cells and Stat3 signaling in obese animals. Nature Medicine 13 89-94. (doi:10.1038/nm1525)

Gao Y, Ottaway N, Schriever SC, Legutko B, Garcia-Caceres C, de la Fuente E, Mergen C, Bour S, Thaler JP, Seeley RJ, et al. 2014 Hormones and diet, but not body weight, control hypothalamic microglial activity. Glia 62 17-25. (doi:10.1002/glia.22580)

Garcia-Caceres C, Fuente-Martin E, Burgos-Ramos E, Granado M, Frago LM, Barrios V, Horvath T, Argente J \& Chowen JA 2011 Differential acute and chronic effects of leptin on hypothalamic astrocyte morphology and synaptic protein levels. Endocrinology 152 1809-1818. (doi:10.1210/en.2010-1252)

Garcia-Caceres C, Quarta C, Varela L, Gao Y, Gruber T, Legutko B, Jastroch M, Johansson P, Ninkovic J, Yi CX, et al. 2016 Astrocytic insulin signaling couples brain glucose uptake with nutrient availability. Cell 166 867-880. (doi:10.1016/j.cell.2016.07.028) http://jme.endocrinology-journals.org

DOI: 10.1530/JME-16-0182
๑) 2017 Society for Endocrinology Printed in Great Britain
Published by Bioscientifica Ltd 
Garcia-Ovejero D, Azcoitia I, Doncarlos LL, Melcangi RC \& GarciaSegura LM 2005 Glia-neuron crosstalk in the neuroprotective mechanisms of sex steroid hormones. Brain Research Reviews $\mathbf{4 8}$ 273-286. (doi:10.1016/j.brainresrev.2004.12.018)

Garcia-Segura LM \& McCarthy MM 2004 Minireview: role of glia in neuroendocrine function. Endocrinology 145 1082-1086. (doi:10.1210/en.2003-1383)

Garcia-Segura LM, Chowen JA \& Naftolin F 1996a Endocrine glia: roles of glial cells in the brain actions of steroid and thyroid hormones and in the regulation of hormone secretion. Frontiers in Neuroendocrinology 17 180-211. (doi:10.1006/frne.1996.0005)

Garcia-Segura LM, Chowen JA \& Naftolin F 1996b Endocrine glia: roles of glial cells in the brain actions of steroid and thyroid hormones and in the regulation of hormone secretion. Frontiers in Neuroendocrinology 17 180-211. (doi:10.1006/frne.1996.0005)

García MA, Millán C, Balmaceda-Aguilera C, Castro T, Pastor P, Montecinos H, Reinicke K, Zúñiga F, Vera JC, Oñate SA, et al. 2003 Hypothalamic ependymal-glial cells express the glucose transporter GLUT2, a protein involved in glucose sensing. Journal of Neurochemistry 86 709-724. (doi:10.1046/j.1471-4159.2003.01892.x)

Ghorbanpoor S, Garcia-Segura LM, Haeri-Rohani A, Khodagholi F \& Jorjani M 2014 Aromatase inhibition exacerbates pain and reactive gliosis in the dorsal horn of the spinal cord of female rats caused by spinothalamic tract injury. Endocrinology 155 4341-4355. (doi:10.1210/en.2014-1158)

Goodman T \& Hajihosseini MK 2015 Hypothalamic tanycytes-masters and servants of metabolic, neuroendocrine, and neurogenic functions. Frontiers in Neuroscience 9 387. (doi:10.3389/ fnins.2015.00387)

Grayson BE, Levasseur PR, Williams SM, Smith MS, Marks DL \& Grove KL 2010 Changes in melanocortin expression and inflammatory pathways in fetal offspring of nonhuman primates fed a high-fat diet. Endocrinology 151 1622-1632. (doi:10.1210/ en.2009-1019)

Gregor MF \& Hotamisligil GS 2007 Thematic review series: Adipocyte Biology. Adipocyte stress: the endoplasmic reticulum and metabolic disease. Journal of Lipid Research 48 1905-1914. (doi:10.1194/jlr. R700007-JLR200)

Guilherme A, Virbasius JV, Puri V \& Czech MP 2008 Adipocyte dysfunctions linking obesity to insulin resistance and type 2 diabetes. Nature Reviews Molecular Cell Biology 9 367-377. (doi:10.1038/nrm2391)

Gupta S, Knight AG, Gupta S, Keller JN \& Bruce-Keller AJ 2012 Saturated long-chain fatty acids activate inflammatory signaling in astrocytes. Journal of Neurochemistry 120 1060-1071. (doi:10.1111/j.14714159.2012.07660.x)

Habib P, Dreymueller D, Ludwig A, Beyer C \& Dang J 2013 Sex steroid hormone-mediated functional regulation of microglia-like BV-2 cells during hypoxia. Journal of Steroid Biochemistry and Molecular Biology 138 195-205. (doi:10.1016/j.jsbmb.2013.06.003)

Hamilton DJ, Minze LJ, Kumar T, Cao TN, Lyon CJ, Geiger PC, Hsueh WA \& Gupte AA 2016 Estrogen receptor alpha activation enhances mitochondrial function and systemic metabolism in high-fat-fed ovariectomized mice. Physiological Reports 4 e12913. (doi:10.14814/phy2.12913)

Hefler CM, Ross AW, \& Morgan PJ 2013 Neuromedin U partily mimics thyroid-stimulating hormone and triggers Wnt-beta-catenin signalling in the photoperiodic response of F344 rats. Journal of Neuroendocrinology 25 1264-1272. (doi:10/1111/jne.12116)

Horvath TL, Sarman B, Garcia-Caceres C, Enriori PJ, Sotonyi P, Shanabrough M, Borok E, Argente J, Chowen JA, Perez-Tilve D, et al. 2010 Synaptic input organization of the melanocortin system predicts diet-induced hypothalamic reactive gliosis and obesity. PNAS 107 14875-14880. (doi:10.1073/pnas.1004282107)

Hsuchou H, He Y, Kastin AJ, Tu H, Markadakis EN, Rogers RC, Fossier PB \& Pan W 2009 Obesity induces functional astrocytic leptin receptors in hypothalamus. Brain 132 889-902. (doi:10.1093/brain/awp029)
Iyer A, Fairlie DP, Prins JB, Hammock BD \& Brown L 2010 Inflammatory lipid mediators in adipocyte function and obesity. Nature Reviews Endocrinology 6 71-82. (doi:10.1038/nrendo.2009.264)

Jayaram B, Pan W, Wang Y, Hsuchou H, Mace A, CornelissenGuillaume GG, Mishra PK, Koza RA \& Kastin AJ 2013 Astrocytic leptin-receptor knockout mice show partial rescue of leptin resistance in diet-induced obesity. Journal of Applied Physiology 114 734-741. (doi:10.1152/japplphysiol.01499.2012)

Kacem K, Lacombe P, Seylaz J \& Bonvento G 1998 Structural organization of the perivascular astrocyte endfeet and their relationship with the endothelial glucose transporter: a confocal microscopy study. Glia 23 1-10. (doi:10.1002/(SICI)10981136(199805)23:1<1::AID-GLIA1>3.0.CO;2-B)

Kim JG, Suyama S, Koch M, Jin S, Argente-Arizón P, Argente J, Liu ZW, Zimmer MR, Jeong JK, Szigeti-Buck K, et al. 2014 Leptin signaling in astrocytes regulates hypothalamic neuronal circuits and feeding. Nature Neuroscience 17 908-910. (doi:10.1038/nn.3725)

Kim DW, Glendining KA, Grattan DR \& Jasoni CL 2016 Maternal obesity in the mouse compromises the blood-brain barrier in the arcuate nucleus of offspring. Endocrinology 157 2229-2242. (doi:10.1210/en.2016-1014)

Lafrance V, Inoue W, Kan B \& Luheshi GN 2010 Leptin modulates cell morphology and cytokine release in microglia. Brain, Behavior, and Immunity 24 358-365. (doi:10.1016/j.bbi.2009.11.003)

Langlet F, Levin BE, Luquet S, Mazzone M, Messina A, Dunn-Meynell AA, Balland E, Lacombe A, Mazur D, Carmeliet P, et al. 2013 Tanycytic VEGF-A boosts blood-hypothalamus barrier plasticity and access of metabolic signals to the arcuate nucleus in response to fasting. Cell Metabolism 17 607-617. (doi:10.1016/j.cmet.2013.03.004)

Lee J, Seroogy KB \& Mattson MP 2002 Dietary restriction enhances neurotrophin expression and neurogenesis in the hippocampus of adult mice. Journal of Neurochemistry 80 539-547. (doi:10.1046/j.0022-3042.2001.00747.x)

Lee DA, Bedont JL, Pak T, Wang H, Song J, Miranda-Angulo A, Takiar V, Charubhumi V, Balordi F, Takebayashi H, et al. 2012 Tanycytes of the hypothalamic median eminence form a dietresponsive neurogenic niche. Nature Neuroscience 15 700-702. (doi:10.1038/nn.3079)

Lee DA, Yoo S, Pak T, Salvatierra J, Velarde E, Aja S \& Blackshaw S 2014 Dietary and sex-specific factors regulate hypothalamic neurogenesis in young adult mice. Frontiers in Neuroscience 8 157. (doi:10.3389/ fnins.2014.00157)

Lei B, Mace B, Dawson HN, Warner DS, Laskowitz DT \& James ML 2014 Anti-inflammatory effects of progesterone in lipopolysaccharidestimulated BV-2 microglia. PLOS ONE 9 e103969. (doi:10.1371/ journal.pone.0103969)

Leloup C, Allard C, Carneiro L, Fioramonti X, Collins S \& Penicaud L 2016 Glucose and hypothalamic astrocytes: more than a fueling role? Neuroscience 323 110-120. (doi:10.1016/j.neuroscience. 2015.06.007)

Li JM, Ge CX, Xu MX, Wang W, Yu R, Fan CY \& Kong LD 2014 Betaine recovers hypothalamic neural injury by inhibiting astrogliosis and inflammation in fructose-fed rats. Molecular Nutrition and Food Research 59 189-202. (doi:10.1002/mnfr.201400307)

Lindqvist A, Mohapel P, Bouter B, Frielingsdorf H, Pizzo D, Brundin P \& Erlanson-Albertsson C 2006 High-fat diet impairs hippocampal neurogenesis in male rats. European Journal of Neurology 13 1385-1388. (doi:10.1111/j.1468-1331.2006.01500.x)

Loane DJ \& Kumar A 2016 Microglia in the TBI brain: The good, the bad, and the dysregulated. Experimental Neurology 275 316-327. (doi:10.1016/j.expneurol.2015.08.018)

Louwe MC, van der Hoorn JW, van den Berg SA, Jukema JW, Romijn JA, van Dijk KW, Rensen PC, Smit JW \& Steendijk P 2012 Genderdependent effects of high-fat lard diet on cardiac function in C57Bl/6J mice. Applied Physiology, Nutrition, and Metabolism 37 214-224. (doi:10.1139/h11-153)

Published by Bioscientifica Ltd. 
Llorens-Martin M, Torres-Aleman I \& Trejo JL 2010 Exercise modulates insulin-like growth factor 1-dependent and -independent effects on adult hippocampal neurogenesis and behaviour. Molecular and Cellular Neuroscience 44 109-117. (doi:10.1016/j.mcn.2010.02.006)

Marty N, Dallaporta M, Foretz M, Emery M, Tarussio D, Bady I, Binnert C, Beermann F \& Thorens B 2005 Regulation of glucagon secretion by glucose transporter type 2 (glut2) and astrocytedependent glucose sensors. Journal of Clinical Investigation $\mathbf{1 1 5}$ 3545-3553. (doi:10.1172/JCI26309)

Melcangi RC, Magnaghi V, Galbiati M \& Martini L 2001 Glial cells: a target for steroid hormones. Progress in Brain Research 132 31-40. (doi:10.1016/s0079-6123(01)32063-0)

Migaud M, Batailler M, Segura S, Duittoz A, Franceschini I \& Pillon D 2010 Emerging new sites for adult neurogenesis in the mammalian brain: a comparative study between the hypothalamus and the classical neurogenic zones. European Journal of Neuroscience 32 2042-2052. (doi:10.1111/j.1460-9568.2010.07521.x)

Milanski M, Degasperi G, Coope A, Morari J, Denis R, Cintra DE, Tsukumo DM, Anhe G, Amaral ME, Takahashi HK, et al. 2009 Saturated fatty acids produce an inflammatory response predominantly through the activation of TLR4 signaling in hypothalamus: implications for the pathogenesis of obesity. Journal of Neuroscience 29 359-370. (doi:10.1523/ JNEUROSCI.2760-08.2009)

Mirzadeh Z, Merkle FT, Soriano-Navarro M, Garcia-Verdugo JM \& Alvarez-Buylla A 2008 Neural stem cells confer unique pinwheel architecture to the ventricular surface in neurogenic regions of the adult brain. Cell Stem Cell 3 265-278. (doi:10.1016/j. stem.2008.07.004)

Morselli E, Fuente-Martin E, Finan B, Kim M, Frank A \& Garcia-Caceres C 2014 Hypothalamic PGC-1 $\alpha$ protects against high-fat diet exposure by regulating ER $\alpha$. Cell Reports 9 633-645. (doi:10.1016/j.celrep.2014.09.025)

Morselli E, Frank AP, Palmer BF, Rodriguez-Navas C, Criollo A \& Clegg DJ 2015 A sexually dimorphic hypothalamic response to chronic high-fat diet consumption. International Journal of Obesity 40 206-209. (doi:10.1038/ijo.2015.114)

Musatov S, Chen W, Pfaff DW, Mobbs CV, Yang X-J, Clegg DJ, Kaplitt MG \& Ogawa S 2007 Silencing of estrogen receptor $\alpha$ in the ventromedial nucleus of hypothalamus leads to metabolic syndrome. PNAS 104 2501-2506. (doi:10.1073/pnas.0610787104)

Nakagawa S, Deli MA, Kawaguchi H, Shimizudani T, Shimono T, Kittel A, Tanaka K \& Niwa M 2009 A new blood-brain barrier model using primary rat brain endothelial cells, pericytes and astrocytes. Neurochemistry International 54 253-263. (doi:10.1016/j. neuint.2008.12.002)

Nedergaard M, Ransom B \& Goldman SA 2003 New roles for astrocytes: redefining the functional architecture of the brain. Trends in Neurosciences 26 523-530. (doi:10.1016/j.tins.2003.08.008)

Nimmerjahn A, Kirchhoff F \& Helmchen F 2005 Resting microglial cells are highly dynamic surveillants of brain parenchyma in vivo. Science 308 1314-1318. (doi:10.1126/science.1110647)

Nokia MS, Lensu S, Ahtiainen JP, Johansson PP, Koch LG, Britton SL \& Kainulainen H 2016 Physical exercise increases adult hippocampal neurogenesis in male rats provided it is aerobic and sustained. Journal of Physiology 594 1855-1873. (doi:10.1113/ JP271552)

Oberheim NA, Goldman SA \& Nedergaard M 2012 Heterogeneity of astrocytic form and function. Methods in Molecular Biology $\mathbf{8 1 4}$ 23-45. (doi:10.1007/978-1-61779-452-0_3)

Ojeda SR, Harms PG \& McCann SM 1975 Effect of inhibitors of prostaglandin synthesis on gonadotropin release in the rat. Endocrinology 97 843-854. (doi:10.1210/endo-97-4-843)

Ojeda SR, Lomniczi A \& Sandau U 2010 Contribution of glial-neuronal interactions to the neuroendocrine control of female puberty.
European Journal of Neuroscience 32 2003-2010. (doi:10.1111/j.14609568.2010.07515.x)

Oyarce K \& Nualart F 2014 Unconventional neurogenic niches and neurogenesis modulation by vitamins. Journal of Stem Cell Research and Therapeutics 4 11. (doi:10.4172/2157-7633.1000184)

Palmer BF \& Clegg DJ 2015 The sexual dimorphism of obesity. Molecular and Cellular Endocrinology 402 113-119. (doi:10.1016/j.mce. 2014.11.029)

Pan W, Hsuchou H, He Y, Sakharkar A, Cain C, Yu C \& Kastin AJ 2008 Astrocyte leptin receptor (ObR) and leptin transport in adult-onset obese mice. Endocrinology 149 2798-2806. (doi:10.1210/en.2007-1673)

Park HR, Park M, Choi J, Park KY, Chung HY \& Lee J 2010 A high-fat diet impairs neurogenesis: involvement of lipid peroxidation and brain-derived neurotrophic factor. Neuroscience Letters 482 235-239. (doi:10.1016/j.neulet.2010.07.046)

Park HR, Kim JY, Park KY \& Lee J 2011 Lipotoxicity of palmitic Acid on neural progenitor cells and hippocampal neurogenesis. Toxicology Research 27 103-110. (doi:10.5487/TR.2011.27.2.103)

Pekny M \& Pekna M 2014 Astrocyte reactivity and reactive astrogliosis: costs and benefits. Physiological Reviews 94 1077-1098. (doi:10.1152/ physrev.00041.2013)

Perez-Martin M, Cifuentes M, Grondona JM, Bermudez-Silva FJ, Arrabal PM, Perez-Figares JM, Jimenez AJ, Garcia-Segura LM \& Fernandez-Llebrez P 2003 Neurogenesis in explants from the walls of the lateral ventricle of adult bovine brain: role of endogenous IGF-1 as a survival factor. European Journal of Neuroscience 17 205-211. (doi:10.1046/j.1460-9568.2003.02432.x)

Pfaff D \& Keiner M 1973 Atlas of estradiol-concentrating cells in the central nervous system of the female rat. Journal of Comparative Neurology 151 121-158. (doi:10.1002/cne.901510204)

Prevot V 2002 Glial-neuronal-endothelial interactions are involved in the control of GnRH secretion. Journal of Neuroendocrinology $\mathbf{1 4}$ 247-255. (doi:10.1046/j.0007-1331.2001.00772.x)

Rivest S 2009 Regulation of innate immune responses in the brain. Nature Reviews Immunology 9 429-439. (doi:10.1038/nri2565)

Rodriguez EM, Blazquez JL, Pastor FE, Pelaez B, Pena P, Peruzzo B \& Amat P 2005 Hypothalamic tanycytes: a key component of brain-endocrine interaction. International Review of Cytology $\mathbf{2 4 7}$ 89-164. (doi:10.1016/S0074-7696(05)47003-5)

Rojczyk-Golebiewska E, Palasz A \& Wiaderkiewicz R 2014 Hypothalamic subependymal niche: a novel site of the adult neurogenesis. Cellular and Molecular Neurobiology 34 631-642. (doi:10.1007/s10571-014-0058-5)

Rubio N, Cerciat M, Unkila M, Garcia-Segura LM \& Arevalo MA 2011 An in vitro experimental model of neuroinflammation: the induction of interleukin- 6 in murine astrocytes infected with Theiler"s murine encephalomyelitis virus, and its inhibition by oestrogenic receptor modulators. Immunology 133 360-369. (doi:10.1111/j.1365-2567.2011.03448.x)

Vesce S, Bezzi P \& Volterra A 1999 The active role of astrocytes in synaptic transmission. Cellular and Molecular Life Sciences 56 11-12. (doi:10.1007/s000180050488)

Sadagurski M \& White MF 2013 Integrating metabolism and longevity through insulin and IGF1 signaling. Endocrinology Metabolism Clinics of North America 42 127-148. (doi:10.1016/j.ecl.2012.11.008)

Salgado M, Tarifeno-Saldivia E, Ordenes P, Millan C, Yanez MJ, Llanos P, Villagra M, Elizondo-Vega R, Martinez F, Nualart F, et al. 2014 Dynamic localization of glucokinase and its regulatory protein in hypothalamic tanycytes. PLOS ONE 9 e94035. (doi:10.1371/journal. pone.0094035)

Sanders NM, Dunn-Meynell AA \& Levin BE 2004 Third ventricular alloxan reversibly impairs glucose counterregulatory responses. Diabetes 53 1230-1236. (doi:10.2337/diabetes.53.5.1230)

Schwarz JM, Sholar PW \& Bilbo SD 2012 Sex differences in microglial colonization of the developing rat brain. Journal of Neurochemistry 120 948-963. (doi:10.1111/j.1471-4159.2011.07630.x) 
Shen L, Wang DQ, Lo CM, Tso P, Davidson WS, Woods SC \& Liu M 2010 Estradiol increases the anorectic effect of central apolipoprotein A-IV. Endocrinology 151 3163-3168. (doi:10.1210/ en.2010-0203)

Shoelson SE, Lee J \& Goldfine AB 2006 Inflammation and insulin resistance. Journal of Clinical Investigation 116 1793-1801. (doi:10.1172/JCI29069)

Shors TJ, Miesegaes G, Beylin A, Zhao M, Rydel T \& Gould E 2001 Neurogenesis in the adult is involved in the formation of trace memories. Nature 410 372-376. (doi:10.1038/35066584)

Stangl D \& Thuret S 2009 Impact of diet on adult hippocampal neurogenesis. Genes and Nutrition 4 271-282. (doi:10.1007/s12263009-0134-5)

Stubbins RE, Holcomb VB, Hong J \& Nunez NP 2012 Estrogen modulates abdominal adiposity and protects female mice from obesity and impaired glucose tolerance. European Journal of Nutrition 51 861-870. (doi:10.1007/s00394-011-0266-4)

Tang CH, Lu DY, Yang RS, Tsai HY, Kao MC, Fu WM \& Chen YF 2007 Leptin-induced IL-6 production is mediated by leptin receptor, insulin receptor substrate-1, phosphatidylinositol 3-kinase, Akt, NF-kappaB, and p300 pathway in microglia. Journal of Immunology 179 1292-1302. (doi:10.4049/jimmunol.179.2.1292)

Tapia-Gonzalez S, Carrero P, Pernia O, Garcia-Segura LM \& Diz-Chaves Y 2008 Selective oestrogen receptor (ER) modulators reduce microglia reactivity in vivo after peripheral inflammation: potential role of microglial ERs. Journal of Endocrinology 198 219-230. (doi:10.1677/ JOE-07-0294)

Tapia-González S, García-Segura LM, Tena-Sempere M, Frago LM, Castellano JM, Fuente-Martín E, García-Cáceres C, Argente J \& Chowen JA 2011 Activation of microglia in specific hypothalamic nuclei and the cerebellum of adult rats exposed to neonatal overnutrition. Journal of Neuroendocrinology 23 365-370. (doi:10.1111/j.1365-2826.2011.02113.x)

Tarttelin MF \& Gorski RA 1971 Variations in food and water intake in the normal and acyclic female rat. Physiology and Behavior $\mathbf{7}$ 847-852. (doi:10.1016/0031-9384(71)90050-3)

Thaler JP, Yi CX, Schur EA, Guyenet SJ, Hwang BH, Dietrich MO, Zhao X, Sarruf DA, Izgur V, Maravilla KR, et al. 2012 Obesity is associated with hypothalamic injury in rodents and humans. Journal of Clinical Investigation 122 153-162. (doi:10.1172/ JCI59660)

Trejo JL, Llorens-Martin MV \& Torres-Aleman I 2008 The effects of exercise on spatial learning and anxiety-like behavior are mediated by an IGF-I-dependent mechanism related to hippocampal neurogenesis. Molecular and Cellular Neuroscience 37 402-411. (doi:10.1016/j.mcn.2007.10.016)

Tsacopoulos M \& Magistretti PJ 1996 Metabolic coupling between glia and neurons. Journal of Neuroscience 16 877-885.

Tu YF, Tsai YS, Wang LW, Wu HC, Huang CC \& Ho CJ 2011 Overweight worsens apoptosis, neuroinflammation and blood-brain barrier damage after hypoxic ischemia in neonatal brain through JNK hyperactivation. Journal of Neuroinflammation $\mathbf{8} 40$. (doi:10.1186/1742-2094-8-40)

Valdearcos M, Robblee MM, Benjamin DI, Nomura DK, Xu AW \& Koliwad SK 2014 Microglia dictate the impact of saturated fat consumption on hypothalamic inflammation and neuronal function. Cell Reports 9 2124-2138. (doi:10.1016/j. celrep.2014.11.018)

Vannucci SJ, Maher F \& Simpson IA 1997 Glucose transporter proteins in brain: delivery of glucose to neurons and glia. Glia 21 2-21. (doi:10.1002/(SICI)1098-1136(199709)21:1<2::AID-GLIA2>3.0.CO;2-C)

Vielkind U, Walencewicz A, Levine JM \& Bohn MC 1990 Type II glucocorticoid receptors are expressed in oligodendrocytes and astrocytes. Journal of Neuroscience Research 27 360-373. (doi:10.1002/ jnr.490270315)

Wang X, Ge A, Cheng M, Guo F, Zhao M, Zhou X, Liu L \& Yang N 2012 Increased hypothalamic inflammation associated with the susceptibility to obesity in rats exposed to high-fat diet. Experimental Diabetes Research 2012 847246. (doi:10.1155/2012/847246)

Wang Y, Jin S, Sonobe Y, Cheng Y, Horiuchi H, Parajuli B, Kawanokuchi J, Mizuno T, Takeuchi H \& Suzumura A 2014 Interleukin-1beta induces blood-brain barrier disruption by downregulating sonic hedgehog in astrocytes. PLOS ONE 9 e110024. (doi:10.1371/journal.pone.0110024)

White MF 2014 IRS2 integrates insulin/IGF1 signalling with metabolism, neurodegeneration and longevity. Diabetes Obesity and Metabolism 16 (Supplement 1) 4-15. (doi:10.1111/dom.12347)

Xu Y, Nedungadi TP, Zhu L, Sobhani N, Irani BG, Davis KE, Zhang X, Zou F, Gent LM, Hahner LD, et al. 2011 Distinct hypothalamic neurons mediate estrogenic effects on energy homeostasis and reproduction. Cell Metabolism 14 453-465. (doi:10.1016/j. cmet.2011.08.009)

Yan BC, Park JH, Ahn JH, Kim IH, Lee JC, Yoo KY, Choi JH, Hwang IK, Cho JH, Kwon YG, et al. 2014 Effects of high-fat diet on neuronal damage, gliosis, inflammatory process and oxidative stress in the hippocampus induced by transient cerebral ischemia. Neurochemical Research 39 2465-2478. (doi:10.1007/s11064-014-1450-8)

Yang L, Qi Y \& Yang Y 2015 Astrocytes control food intake by inhibiting AGRP neuron activity via adenosine A1 receptors. Cell Reports $\mathbf{1 1}$ 798-807. (doi:10.1016/j.celrep.2015.04.002)

Yi CX, Al-Massadi O, Donelan E, Lehti M, Weber J, Ress C, Trivedi C, Müller TD, Woods SC \& Hofmann SM 2012 Exercise protects against high-fat diet-induced hypothalamic inflammation. Physiology and Behavior 106 485-490. (doi:10.1016/j.physbeh.2012.03.021)

Zhong Y, Zhou LJ, Ren WJ, Xin WJ, Li YY, Zhang T \& Liu XG 2010 The direction of synaptic plasticity mediated by C-fibers in spinal dorsal horn is decided by Src-family kinases in microglia: the role of tumor necrosis factor-alpha. Brain, Behavior, and Immunity 24 874-880. (doi:10.1016/j.bbi.2010.01.007)

Zhu SQ, Kum W, Ho SK, Young JD \& Cockram CS 1990 Structurefunction relationships of insulin receptor interactions in cultured mouse astrocytes. Brain Research 529 329-332. (doi:10.1016/00068993(90)90846-4)

Zhu Z, Liu X, Senthil Kumar SP, Zhang J \& Shi H 2013 Central expression and anorectic effect of brain-derived neurotrophic factor are regulated by circulating estradiol levels. Hormones and Behavior 63 533-542. (doi:10.1016/j.yhbeh.2013.01.009)

Ziko I, De Luca S, Dinan T, Barwood JM, Sominsky L, Cai G, Kenny R, Stokes L, Jenkins TA \& Spencer SJ 2014 Neonatal overfeeding alters hypothalamic microglial profiles and central responses to immune challenge long-term. Brain, Behavior, and Immunity 41 32-43. (doi:10.1016/j.bbi.2014.06.014)

Received in final form 19 September 2016

Accepted 18 November 2016

Accepted Preprint published online 18 November 2016 http://jme.endocrinology-journals.org

DOI: 10.1530/JME-16-0182
() 2017 Society for Endocrinology Printed in Great Britain
Published by Bioscientifica Ltd 